\title{
PENDIDIKAN PESANTREN SEBAGAI MODEL YANG IDEAL DALAM PENDIDIKAN ISLAM
}

\author{
Syaiful Anam \\ E-mail: syaiful_1980@yahoo.com \\ Dosen Sekolah Tinggi Ilmu Tarbiyah Madani Yogyakarta
}

\begin{abstract}
Abstrak
Pendidikan Islam sejalan dengan konsep pendidikan menurut Al Qur'an dirangkum dalam tiga konsep pendidikan: tarbiyah, ta'lim dan ta'dib. Pendidikan dalam konsep tarbiyah lebih menjelaskan kepada manusia bahwa Tuhan memberikan pendidikan melalui utusan-Nya yaitu Rasulullah dan kemudian Rasul sampaikan kepada para ulama, kemudian para ulama menyampaikan kepada manusia. Sedangkan pendidikan dalam konsep ta'lim adalah proses mentransfer ilmu untuk meningkatkan kecerdasan peserta didik. Maka ta'dib adalah proses pendidikan yang lebih fokus pada bimbingan moral peserta didik. Konsep pendidikan menurut Al-Qur'an dirangkum dalam ayat-ayat yang berkaitan dengan pendidikan dalam Al-Qur'an itu sendiri seperti dalam ayat al-Baqarah ayat 31-34, 129, dan 151 menggambarkan pelajaran yang diberikan Tuhan kepada Nabi Adam. Alaihissalaam, dan mata pelajaran yang diberikan Rasulullah sallawlahu alaihi wasallam kepada umatnya. Surat Luqman ayat 13-14 berisi konsep pendidikan dasar yaitu pendidikan orang tua kepada anak-anak.
\end{abstract}

\section{Kata kunci: Pondok Pesantren, Pendidikan Ideal, Kurikulum}

\section{Abstract}

Islamic education in line with the concept of education according to the Qur'an summarized in three concepts of education: tarbiyah, ta'lim and ta'dib. Education in the concept of tarbiyah more explains to humans that God provides education through His messenger that is the Messenger of Allah and then the Apostle convey to the scholars, then the scholars convey to humans. While education in the concept of ta'lim is the process of transferring science to improve the intellectuality of learners. Then ta'dib is an educating process that is more focused on the moral guidance of learners. The concept of education according to the Qur'an is summarized in verses relating to education in the Qur'an itself as in the verses of al-Baqarah verses 31-34, 129, and 151 describe the lesson that God gave to the Prophet Adam Alaihissalaam, and the subjects of education given Rasulullah sallawlahu alaihi 
Syaiful Anam : Pendidikan Pesantren Sebagai Model Yang Ideal Dalam Pendidikan Islam

wasallam to his people. Letter Luqman verse 13-14 contains the concept of primary education namely parent education to children.

\section{Keywords: Islamic Boarding School, Ideal Education, Curriculum}

\section{A. PENDAHULUAN}

Sebagai generasi penerus bangsa, anak didik diharapkan mampu mengoptimalkan segenap potensi fitrahnya untuk melakukan gerakan revolusioner bagi kemajuan bangsa kedepan. Gerakan revolusioner ini bisa tercapai apabila anak didik tidak terjebak dengan gempuran modernitas yang membawa perubahan dan warna lain yang mengancam moralitas anak bangsa secara keseluruhan. Pendidikan diakui sebagai solusi utama dalam menumbuhkembangkan potensi dan skill anak didik agar menjadi generasi siap pakai dan mampu menghadapi segala tantangan yang menyangkut perubahan soial dalam kehidupan masyarakat (Takdir, 2012: 7)

Pendidikan Islam berupaya mengembangkan semua aspek dalam kehidupan manusia yang meliputi spiritual, intelektual, imajinasi, keilmiahan dan nilai-nilai, baik secara individu ataupun berkelompok serta senantiasa memberikan dorongan bagi kedinamisan aspek-aspek di atas menuju kebaikan dan mencapai kesempurnaan hidup baik dalam hubungan dengan Al-Khaliq, dengan sesama manusia dan dengan alam. Sebagai bagian dari sistem pendidikan nasional lembaga pendidikan Islam memiliki tanggungjawab yang sama dengan lembaga pendidikan lain dalam rangka mewujutkan asumsi diatas. Secara ideal, pendidikan Islam berusaha mengantarkan manusia mencapai keseimbangan pribadi secara menyeluruh. Hal ini 
Syaiful Anam : Pendidikan Pesantren Sebagai Model Yang Ideal Dalam Pendidikan Islam

dapat dilakukan melalui latihan-latihan kejiwaan, akal pikiran, kecerdasan, perasaan ataupun panca indra.

Oleh karena itu, dengan format seperti ini, maka pendidikan Islam telah merangkul semua prinsip tujuan pendidikan. Jika dibandingkan dengan pendidikan pada umumnya, maka beban yang dipikul oleh pendidikan Islam amatlah berat. Karena tujuan akhir pendidikan Islam tidak hanya pencapaian kebahagian dunia tetapi juga kebahagiaan akhirat. Hal ini akan berrarti pula, bahwa pendidikan islam mengandung konsep agama (din) konsep manusia (insan), konsep ilmu (ilm dan ma"rifat), konsep kebijakan (hikmah), konsep keadilan („adl), konsep amal (amal sebagai adab) dan konsep perguruan tinggi (kuliyatul jami"ah). Dengan perpaduan konsep-konsep inilah manusia mampu meraih kebahagian dunia akhirat. (Usa, 1991: 8-9)

Islam sejak awal kemunculannya telah memperlihatkan pentingnya pendidikan bagi kehidupan manusia. Ayat pertama yang diterima Nabi Muhammad adalah Iqra'yang mengandung pesan tentang perintah memberdayakan potensi akal yang dimiliki manusia, dan itu merupakan inti pendidikan dalam Islam. Namun, perlu diakui bahwa pendidikan Islam ketika itu belum mempunyai bentuk yang formal dan sistematis, karena peranan pendidikan pada awal perkembangan Islam masih sebatas upaya-upaya penyebaran dakwah Islam berupa penanaman ketauhidan dan praktek-praktek ritual keagamaan. Keadaan di atas berlangsung sejak Nabi Muhammad masih hidup hingga sampai pada suatu zaman dimana pemikiran umat Islam mulai bersentuhan dengan peradaban dan kebudayaan dari luar Islam. 
Pesantren, jika disandingkan dengan lembaga pendidikan yang pernah muncul di Indonesia, merupakan sistem pendidikan tertua saat ini dan dianggap sebagai produk budaya Indonesia. Pendidikan ini semula merupakan pendidikan agama Islam yang dimulai sejak munculnya masyarakat Islam di Nusantara pada abad ke-13. Beberapa abad kemudian penyelenggaraan pendidikan ini semakin teratur dengan munculnya tempattempat pengajian. Bentuk ini kemudian berkembang dengan pendirian tempat-tempat menginap bagi para pelajar (santri), yang kemudian disebut Pesantren.

Meskipun bentuknya masih sangat sederhana, pada waktu itu pendidikan pesantren merupakan satu-satunya lembaga pendidikan yang tersetruktur, sehingga pendidikan ini di anggap sangat bergengsi. Di lembaga inilah kaum muslimin Indonesia mendalami dasar-dasar Islam, khususnya menyangkut praktik kehidupan keagamaan (Umar, 2012: 1).

\section{B. PEMbahasan}

1. Pengertian Pendidikan Pesantren

Pengertian pendidikan Islam yaitu sebuah proses yang dilakukan untuk menciptakan manusia-manusia yang seutuhnya; beriman dan bertaqwa kepada Tuhan serta mampu mewujudkan eksistensinya sebagai khalifah Allah dimuka bumi, yang berdasarkan kepada ajaran Al-qur'an dan Sunnah, maka tujuan dalam konteks ini terciptanya insan kamil setelah proses pendidikan berakhir (Arif, 2002: 9).

Sedangkan Prof. H. Muhammad Daud Ali, S.H (1995: 137) berpendapat bahwa pendidikan adalah usaha sadar yang dilakukan oleh manusia untuk mengembangkan potensi manusia lain atau memindahkan nilai-nilai yang dimilikinya 
kepada orang lain dalam masyarakat. Proses pemindahan nilai itu dapat dilakukan dengan berbagai cara, diantaranya adalah, pertama melalui pengajaran yaitu proses pemindahan nilai berupa (Ilmu) pengetahuan dari seorang guru kepada murid-muridnya dari suatu generasi kegenerasi berikutnya. kedua melalui pelatihan yang dilaksanakan dengan jalan membiasakan seseorang melakukan pekerjaan tertentu untuk memperoleh keterampilan mengerjakan pekerjaan tersebut. ketiga melalui indoktrinnasi yang diselenggarakan agar orang meniru atau mengikuti apa saja yang diajarkan orang lain tanpa mengijinkan si penerima tersebut mempertanyakan nilai-nilai yang diajarkan. (Arif, 2002: 10).

Terkadang apabila ingin membahas seputar Islam dalam Pendidikan merupakan suatu hal yang sangat menarik terutama dalam kaitannya dengan upaya pembangunan Sumber Daya Manusia muslim, sebagaimana Islam di pahami sebagai pegangan hidup yang diyakini mutlak kebenarannya akan merai arah dan landasan etis serta moral pendidikan, atau dengan kata lain hubungan antara Islam dan pendidikan bagaikan dua sisi keping mata uang. Artinya, Islam dan pendidikan mempunyai hubungan filosofis yang sangat mendasar baik secara ontologis, epistimologis maupun aksiologis (Tafsir, 2006:15)

Pemikiran di atas sejalan dengan falsafah bahwa sebuah usaha yang tidak mempunyai tujuan tidak akan mempunyai arti apa-apa. Ibarat seseorang yang bepergian tak tentu arah maka hasilnya adalah tidak lebih dari pengalaman selam perjalanan. Pada dasarnya pendidikan merupakan usaha yang dilakukan sehingga dalam penerapannya ia tak kehilangan arah dan pijakn. Namun sebelum masuk dalam 
pembahasan mengenai fungsi dan tujuan pendidikan Islam terlebih dahulu perlu dijelaskan apa pengertian Pendidikan Pesantren itu sendiri.

Dalam makalahnya yang berjudul "Model-model Perguruan Tinggi Islam" Zarkowi Soejati mengemukakan, pendidikan Islam paling tidak mempunyai tiga pengertian. Pertama: lembaga pendidikan Islam itu pendirian dan penyelenggaraannya didorong oleh hasrat mengejawantahkan nilai-nilai Islam yang tercermin dalam nama lemabaga pendidikan itu dan kegiatan-kegiatan yang diselenggarakan. Kedua; lembaga pendidikan memberikan perhatian dan menyelenggarakan kajian tentang Islam yang tercermin dalam program sebagai ilmu yang diperlukanseperti ilmuilmu lain yang menjkadi program kajian lembaga pendidikan Islam yang bersangkutan. Ketiga; mengandung kedua pengertian di atas dalam arti lembaga tersebut memperlakukan Islam sebagai sumber nilai bagi sikap dan tingkah laku yang harus tercermin dalam penyelenggaraannya maupun sebagai bidang kajian yang tercermin dalam program kajiannya (KBBI, 2019: 300).

Mohamad Natsir berpendapat bahwa pendidikan menurut adalah suatu pimpinan jasmani dan ruhani menuju kesempurnaan kelengkapan arti kemanusiaan dengan arti sesungguhnya (Ali dan Daud, 1995: 137). Menurut UndangUndang Sistem Pendidikan Nasional (Sisdiknas) No. 20 tahun 2003 Pasal 1 ayat 1, pendidikan adalah usaha sadar dan terencana untuk mewujudkan suasana belajar dan proses pembelajaran agar peserta didik secara aktif mengembangkan potensi dirinya untuk memiliki kekuatan spiritual keagamaan, pengendalian diri, serta keterampilan yang 
diperlukan dirinya, masyarakat, bangsa dan negara (Natsir, 1973: 82).

Kemudian pengertian pendidikan Islam menurut Dr. Yusuf Qardawi sebagaimana dikutip oleh Dr. Azyumardi Azra memberi pengertian pendidikan Islam yaitu pendidikan manusia seutuhnya, akal dan hatinya, rohani dan jasmaninya, akhlak dan keterampilannya. Karena pendidikan Islam menyiapkan manusia untuk hidup dan menyiapkan untuk menghadapi masyarakat dengan segala kebaikan dan kejahatannya, manis pahitnya. (Azra,1998: 8).

Endang Saefuddin Anshari (1976: 85) memberi pengertian secara lebih tehnis, pendidikan Islam sebagai proses bimbingan (pimpinan, tuntunan dan usulan) oleh subyek didik terhadap perkembangan jiwa (pikiran, perasaan, kemauan, intuisi), dan raga obyek didik dengan bahan-bahan materi tertentu, pada jangka waktu tertentu, dengan metode tertentu dan dengan alat perlengkapan yang ada ke arah terciptanya pribadi tertentu disertai evaluasi sesuai ajaran Islam. Pendidikan Islam adalah suatu proses pembentukan individu berdasarkan ajaran-ajaran Islam yang diwahyukan Allah subhanahu wata'ala kepada Nabi Muhammad shollallohu alaihi wasallam.

Berdasarkan beberapa pengertian diatas, terdapat perbedaan antara pengertian pendidikan secara umum dengan pendidikan Islam. Pendidikan secara umum merupakan proses pemindahan nilai-nilai budaya dari satu generasi ke generasi berikutnya. Perbedaan tersebut dalam hal nilai-nilai yang dipindahkan (diajarkan). Dalam pendidikan Islam, nilai-nilai yang dipindahkan berasal dari 
sumber-sumber nilai Islam yakni Al-Qur'an, Sunah dan Ijtihad para ulama salaf.

Jadi, pendidikan pesantren tidak mungkin terlepas dari pendidikan Islam, yaitu pendidikan yang merupakan proses bimbingan baik jasmani dan rohani berdasarkan ajaran-ajaran agama Islam yang bersumber dari al-Qur'an dan hadist dan ijtihad menuju kepada terbentuknya kepribadian muslim yang berakhlaq baik, beramal sholih sesuai sunnah, berwawasan qur'ani, berhati robbani.

2. Tujuan Dan Fungsi Pendidikan Pesantren

Sebelum lebih jauh menjelaskan tujuan pendidikan Islam terlebih dahulu apa sebenarnya makna dari "tujuan" tersebut. Secara etimologi tujuan adalah "arah, maksud atau haluan. Terminologinya tujuan berarti sesuatu diharapkan tercapai setelah sebuah usaha atau kegiatan selesai. Oleh H.M. Arifin menyebutkan, bahwa tujuan proses pendidikan Islam adalah "idealitas (cita-cita) yang mengandung nilai-nilai Islam yang hendak dicapai dalam proses kependidikan yang berdasarkan ajaran Islam secara bertahap.

Maka secara umum, tujuan pendidikan Islam terbagi kepada: pertama tujuan umum adalah tujuan yag akan dicapai dengan semua kegiatan pendidikan baik pengajaran atau dengan cara lain. kedua, tujuan sementara adalah tujuan yang akan dicapai setelah anak didik diberi sejumlah pengalamn tertentu yang direncanakan dalam sebuah kurikulum. ketiga, tujuan akhir adalah tujuan yang dikehendaki agar peserta didik menjadi manusia-manusia sempurna (insan kamil) setelah ia menghabisi sisa hidupnya. Sementara keempat tujuan oprasional adalah tujuan praktis 
yang akan dicapai dengan sejumlah kegiatan pendidikan tertentu (Arifin, 1991: 224)

Sementara itu dalam Konferensi Internasional Pertama tentang Pendidikan Islam di Mekah pada tahun 1977 merumuskan tujuan pendidikan Islam sebagai berikut:

"Pendidikan bertujuan mencapai pertumbuhan kepribadian manusia yang menyeluruh secara seimbang melalui latihan jiwa, intelek, diri manusia yang rasional; perasaan dan indera. Oleh karena itu pendidikan harus mencakup pertumbuhan manusia dalam segala aspeknya; spritual, intelektual, imajinatif, fisik, ilmiah, bahasa, baik secara individu maupun secara kolektif, dan mendorong semua aspek ini ke arah kebaikan untuk mencapai kesempurnaan. Tujuan akhir pendidikan muslim terletak pada perwujudan ketundukkan yang sempurna kepada Allah baik secara pribadi, komunitas, maupun seluruh umat manusia”. (Azra, 1998: 8)

Konsep di atas sejalan dengan rumusan tujuan pendidikan Islam, yaitu meningkatkan keimanan, pemahaman, penghayatan dan pengalaman anak tentang Islam, sehingga menjadi manusia muslim yang beriman dan bertaqwa kepada Allah swt serta berakhlak mulia dalam kehidupan pribadi, bermasyarakat, berbangsa dan bernegara. Sehingganya dalam konteks ini pendidikan Islam haruslah senantiasa mengorientasikan diri kepada menjawab kebutuhan dan tantangan yang muncul dalam masyarakat kita sebagai konsekuensi logis dari perubahan.

Dapat pula katakan, bahwa tujuan pendidikan Islam adalah kepribadian muslim, yaitu sesuatu kepribadian yang seluruh aspeknya dijiwai oleh ajaran Islam. Orang yang 
dalam kepribadian muslim dalam Al-Qur'an disebut "Muttaqin" karena itu Pendidikan Islam berarti pula pembentukan manusia yang bertakwa, sebagaimana konsep pendidikan nasional yang dituangkan dalam tujuan pendidikan nasional yang akan membentuk manusia yang bertaqwa kepada Tuhan Yang Maha Esa.

Dengan demikian jika dilakukan rekonstruksi, maka menurut Islam ilmu yang selayaknya dikuasai manusia merupakan perpaduan dari ilmu - ilmu yang diperoleh manusia melalui kawasan alam semesta dengan ilmu yang dikirim melalui wahyu yang dapat ditangkap oleh para nabi dan rasul. Dalam perspektif pendidikan Islam yang menyiapkan manusia agar dapat melakukan perannya, baik sebagai khalifah maupun sebagai 'abd, maka ilmu yang wajib dituntut adalah ilmu yang sifatnya terpadu, dan inilah ciri khas pendidikan Islam.

Dilihat dari tujuan pendidikan di atas maka dengan sendirinya terimplisit fungsi pendidikan Islam. Dapat diartikan fungsi Pendidikan Islam adalah untuk menjaga keutuhan unsur-unsur individu anak didik dengan mengoptimalkan potensinya dalam garis keridhaan Allah, serta mengoptimalkan perkembangannya untuk bertahan hidup terhadap aspek keterampilan setiap anak.

Pendidikan Islam adalah pendidikan terbuka. Artinya Islam mengakui adanya perbedaan, tetapi perbedaannya yang hakiki ditentukan oleh amalnya. Oleh karena itu pendidikan Islam pada dasarnya terbuka, demokratis, dan universal. Keterbukaan tersebut ditandai dengan kelenturan untuk mengadopsi (menyerap) unsur-unsur positif dari luar, sesuai perkembangan dan kebutuhan masyarakatnya, dan tetap 
menjaga dasar-dasarnya yang original yang bersumber pada Al-Qur'an dan Al-hadits. (Azra, 1998: 18)

Singkatnya, pendidikan Islam secara ideal berfungsi membina dan menyiapkan anak-anak dalam keluarga termasuk anak didik yang berilmu, berteknologi, berketerampilan tinggi dan sekaligus beriman dan beramal saleh. Oleh karena itu penjabaran materi pendidikan Islam tidak hanya berkisar pada hal-hal yang berkaitan dengan masalah-masalah ubudiyah yang khas (khusus) seperti shalat, puasa, zakat, haji dan lain-lain, akan tetapi ubudiyah yang lebih umum dan luas, yaitu pengembangan ilmu sosial sehingga anak dapat berinteraksi dengan lingkungannya secara baik maupun pengembangan pengetahuan dan teknologi yang sangat bermanfaat dalam meningkatkan taraf hidup dan kesejahteraan.

Dengan demikian pendidikan menyandang misi keseluruhan aspek kebutuhan hidup serta perubahanperubahan yang terjadi. Akibat logisnya, pendidikan senantiasa mengundang pemikiran dan kajian baik secara konseptual maupun oprasionalnya. Sehingga diperoleh relevansi dan kemampuan menjawab tantangan serta memcahkan masalah-masalah yang dihadapi oleh umat Islam.

\section{Model Pendidikan di Pesantren}

Merujuk kepada informasi al-Qur'an pendidikan mencakup segala aspek jagat raya ini, bukan hanya terbatas pada manusia semata, yakni dengan menempatkan Allah sebagai Pendidik Yang Maha Agung. Konsep pendidikan alQur'an sejalan dengan konsep pendidikan Islam yang dipresentasikan melalui kata tarbiyah, ta'lim dan ta'dib. 
Tarbiyah berasal dari kata Robba, pada hakikatnya merujuk kepada Allah selaku Murabby (pendidik) sekalian alam. Kata Rabb (Tuhan) dan Murabby (pendidik) berasal dari akar kata seperti termuat dalam ayat al-Qur'an yang artinya: "Dan rendahkanlah dirimu terhadap mereka berdua dengan penuh kesayangan dan ucapkanlah: "Wahai Tuhanku, kasihilah mereka keduanya, sebagaimana mereka berdua Telah mendidik Aku waktu kecil". (Q.S. Al-Israa:24)

Menurut Syed Naquib Al-Attas (1987: 20), al-tarbiyah mengandung pengertian mendidik, memelihara menjaga dan membina semua ciptaan-Nya termasuk manusia, binatang dan tumbuhan. Sedangkan Samsul Nizar (2001: 90) menjelaskan kata al-tarbiyah mengandung arti mengasuh, bertanggung jawab, memberi makan, mengembangkan, memelihara, membesarkan, menumbuhkan dan memproduksi baik yang mencakup kepada aspek jasmaniah maupun rohaniah.

Kata Rabb di dalam Al-Qur'an diulang sebanyak 169 kali dan dihubungkan pada obyek-obyek yang sangat banyak. Kata Rabb ini juga sering dikaitkan dengan kata alam, sesuatu selain Tuhan. Pengkaitan kata Rabb dengan kata alam tersebut seperti pada surat Al-A'raf ayat 61 yang artinya: "Nuh menjawab: "Hai kaumku, tak ada padaku kesesatan sedikitpun tetapi Aku adalah utusan dari Tuhan semesta alam".

Pendidikan diistilahkan dengan ta'dib, yang berasal dari kata kerja "addaba". Kata al-ta'dib diartikan kepada proses mendidik yang lebih tertuju pada pembinaan dan penyempurnaan akhlak atau budi pekerti peserta didik (Samsul Nizar, 2001: 90). Kata ta'dib tidak dijumpai langsung 
dalam al-Qur'an, tetapi pada tingkat operasional, pendidikan dapat dilihat pada praktek yang dilakukan oleh Rasulullah. Rasul sebagai pendidik agung dalam pandangan pendidikan Islam, sejalan dengan tujuan Allah mengutus beliau kepada manusia yaitu untuk menyempurnakan akhlak. Allah juga menjelaskan, bahwa sesungguhnya Rasul adalah sebaik-baik contoh teladan bagi kamu sekalian (Samsul Nizar, 2001: 91).

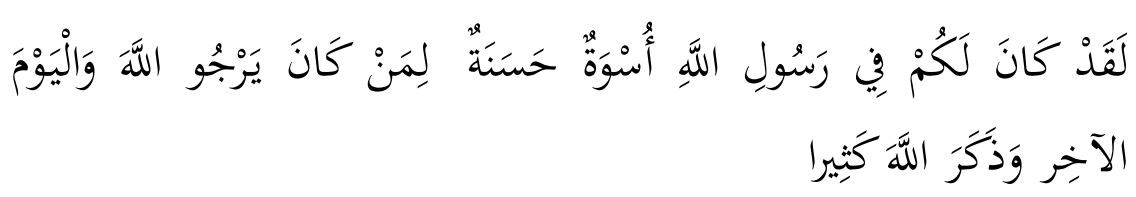

Artinya:

"Sesungguhnya telah ada pada diri Rasulullah itu suri tauladan yang baik bagimu (yaitu) bagi orang yang mengharap rahmat Allah dan kedatangan hari kiamat dan dia banyak menyebut Allah" ( QS. Al-Ahzab: 21)

Selanjutnya Rasulullah Saw meneruskan wewenang dan tanggung jawab tersebut kepada kedua orang tua selaku pendidik kodrati. Dengan demikian status orang tua sebagai pendidik didasarkan atas tanggung jawab keagamaan, yaitu dalam bentuk kewajiban orang tua terhadap anak, mencakup memelihara dan membimbing anak, dan memberikan pendidikan akhlak kepada keluarga dan anak-anak.

Pendidikan disebut dengan ta'lim yang berasal dari kata 'alama berkonotasi pembelajaran yaitu semacam proses transfer ilmu pengetahuan. Dalam kaitan pendidikan ta'lim dipahami sebagai sebagai proses bimbingan yang dititikberatkan pada aspek peningkatan intelektualitas peserta didik. Proses pembelajaran ta'lim secara simbolis dinyatakan dalam informasi al-Qur'an ketika penciptaan Adam alahis salam oleh Allah subhanahu wata'ala. Adam 
alahis salam sebagai cikal bakal dari makhluk berperadaban (manusia) menerima pemahaman tentang konsep ilmu pengetahuan langsung dari Allah Swt, sedang dirinya sama sekali kosong. Sebagaimana tertulis dalam surat al-Baqarah ayat 31 dan 32: "Dan Dia mengajarkan kepada Adam namanama (benda-benda) seluruhnya, kemudian mengemukakannya kepada para malaikat lalu berfirman: "Sebutkanlah kepada-Ku nama benda-benda itu jika kamu memang orang-orang yang benar. Mereka menjawab, "Maha suci Engkau, tidak ada yang kami ketahui selain dari apa yang telah Engkau ajarkan kepada kami, sesungguhnya Engkaulah yang Maha Mengetahui lagi Maha Bijaksana."( QS. Al-Baqoroh: 31-32)

Dari ketiga konsep diatas, terlihat hubungan antara tarbiyah, ta'lim dan ta'dib. Ketiga konsep tersebut menunjukkan hubungan teologis (nilai tauhid) dan teleologis (tujuan) dalam pendidikan Islam sesuai al-Qur'an yaitu membentuk akhlak al-karimah. Maka, ada beberapa unsur dalam pesantren, yaitu:

a. Kyai

Kyai merupakan unsur kunci dalam pesantren, karena itu sikap hormat (takzim) dan kepatuhan mutlak terhadap kyai adalah salah satu nilai pertama yang ditanamkan kepada santri. Daud Rasyid menambahkan, kyai dan santri akan berinteraksi secara kontinyu dan lama di pesantren, sehingga seluruh kegiatan santri dapat diawasi dan dibentuk oleh kyai. Kyai dengan karomahnya, adalah orang yang senantiasa dapat memahami keagungan Allah. Dengan demikian, kyai dianggap memiliki kedudukan yang tidak terjangkau, utamanya 
Syaiful Anam : Pendidikan Pesantren Sebagai Model Yang Ideal Dalam Pendidikan Islam

oleh orang biasa. Menurut Saiful Akhyar Lubis,menyatakan bahwa "Kyai adalah tokoh sentral dalam suatu pondokpesantren, maju mundurnya pondok pesantren ditentukan oleh wibawa dan kharisma sang kyai. (Lubis, 2007: 169).

Terdapat tiga perkataan kyai yang dipakai untuk tiga jenis gelar yang berbeda (dalam bahasa Jawa), yaitu: 1 .Sebagai gelar yang diberikan oleh masyarakat kepada orang ahli agama Islam yang memiliki atau menjadi pimpinan pesantren dan mengajar kitab-kitab Islam klasik kepada para santrinya.; 2. Sebagai gelar kehormatan bagi barang-barang yang dianggap keramat; contohnya, "kyai garuda kencana" dipakai untuk sebutkan kereta emas yang ada di Kraton Yogyakarta; 3. gelar kehormatan bagi orang-orang tua pada umumnya.

Tidak jauh beda dengan makna ulama, kyai di lingkungan pesantren berarti sarjana muslim, atau personifikasi orang yang menguasai agama Islam dalam bidang disiplin ilmu.. Kyai termasuk unsur yang paling esensial dari suatu pesantren. Lazimnya pertumbuhan suatu pesantren semeta-mata bergantung pada kemampuan pribadi kyainya. Namun kata kyai dalam bahasa Jawa dipakai untuk tiga makna gelar, yaitu:

1) Gelar kehormatan bagi benda-benda keramat. Umpamanya kyai garuda kencana (kereta yang ada di keraton Yogyakarta).

2) Gelar kehormatan untuk orang tua pada umumnya.

3) Gelar yang diberikan masyarakat kepada seorang ahli agama Islam yang memiliki atau menjadi pemimpin pesantren dan mengajarkan kitab-kitab klasik kepada 
santrinya. Selain bergelar kyai, ia juga sering disebut dengan alim atau alim ulama, yaitu artinya orang yang mahir dalam pengetahuan agamanya.

b. Masjid

Secara harfiah, masjid berasal dari Bahasa Arab yaitu sajada, yasjudu, sujudan. Dalam Kamus alMunawwir (1997: 610), berarti membungkuk dengan khidmat. Dari akar kata tersebut, terbentuklah kata masjid yang merupakan kata benda yang menunjukkan arti tempat sujud (isim makan dari fi'il sajada).

Masjid merupakan elemen yang paling penting, sebab masjid merupakan tempat pusat kegiatan yang ada bagi umat Islam. Pendidikan formal yang ada dalam Islam berawal dari Masjid, dengan kegiatan halaqah yang diadakan didalamnya. Begitu juga daIan pondok pesantren, masjid di jadikan sebagai pusat pendidikan, dan merupakan manivestasi universalisme dari sistem pendidikan Islam tradisionaI. Dengan kata lain, kesinambungan sistem pendidikan Islam tradisional terpusat pada masjid. Selain itu, seorang kyai yang ingin mengembangkan pasantren, bisanya yang pertama didirikan adalah masjid di dekat rumahnya, karena dengan demikian berarti ia telah memulai sesuatu dengan simbol keagaman, yaitu Masjid yang merupakan rumah Allah, dimana di dalamnya dipenuhi dengan rahmat dan ridho Allah Subhanahu wata'ala.

c. Santri

Santri adalah nama lain dari siswa atau murid. Nama santri dipakai khusus untuk lembaga pendidikan pondok pesantren, yaitu orang-orang yang tengah 
menuntut ilmu di lembaga pendidikan pesantren (Bawani, 1993: 90). Menurut Zamaksani Dhofier, ada dua kelompok santri, yaitu:

1) Santri mukim: yaitu murid-murid yang berasal dan daerah yang jauh dan menetap dalam pondok pesantren.

2) Santri kalong: yaitu murid-murid yang berasal dari desa-desa di sekeliling pesantren, yang biasanya tidak menetap di pesantren (Bawani, 1993: 93).

d. Pondok Pesantren

Pondok pesantren merupakan lembaga pendidikan Islam tradisional dan modern yang lebih menekankan aspek moralitas kepada santri dalam kehidupan ini karenanya untuk nilai-nilai tersebut diperlukan gemblengan yang matang kepadanya, dan untuk memudahkan itu diperlukan sebuah asrama sebagai tempat tinggal dan belajar di bawah bimbingan seorang kyai.

Gelar kyai, sebagaimana diungkapkan Mukti Ali yang dikutip Imam Bawani, biasanya diperoleh seseorang berkat kedalaman ilmu keagamaannya, kesungguhan perjuangannya ditengah umat, kekhusyu'annya dalam beribadah, dan kewibawaannya sebagai pemimpin. Sehingga semata hanya karena faktor pendidikan tidak dapat menjamin bagi seseorang untuk memperoleh predikat kyai, melainkan faktor bakat dan seleksi alamiah yang lebih menentukannya (Dewan Redaksi, 1993: 105).

Di lingkungan pesantren, seorang kyai adalah hirarki kekuasaan satu-satunya yang ditegakkan di atas kewibawaan moral sebagai pengawas para santri dari 
kemungkingan melangkah ke arah kesesatan, kekuasaan ini memiliki perwatakan absolut sehingga santri senantiasa terikat dengan kyainya seumur hidupnya, minimal sebagai sumber inspirasi dan sebagai penunjang moral dalam kehidupan pribadinya (Wahid, 2001 6-7).

Di masyarakat, kyai merupakan bagian dari kelompok elite dalam struktur sosial, politik dan ekonomi, yang memiliki pengaruh yang amat kuat di masyarakat, biasanya mereka memiliki suatu posisi atau kedudukan yang menonjol baik pada tingkat lokal maupun nasional. Dengan demikian merupakan pembuat keputusan yang efektif dalam sistem kehidupan sosial, tidak hanya dalam kehidupan keagamaan tetapi juga dalam soal-soal politik.

Ada tiga alasan mengapa pesantren harus menyediakan asrama bagi santri, yaitu: Pertama, kemasyuran seorang kyai dan kedalaman ilmu pengetahuannya tentang Islam menarik santri dari jauh, untuk dapat menggali ilmu dari kyai tersebut secara teratur dan dalam waktu yang lama. Para santri tersebut harus meninggalkan kampung halamannya, dan menetap di kediaman kyai. Kedua, hampir semua pesantren berada di desa desa-desa, di mana tidak tersedia perumahan (akomodasi) yang cukup untuk dapat menampung para santr, dengan demkian perlulah adanya suatu asrama khusus bagi para santri.

Ketiga, adalah sikap timbal balik antara kyai dan santri, dimana para santri menganggap para kyainya seolah-olah sebagai bapaknya sendiri, sedangkan kyai menganggap para santri sebagai titipan Tuhan yang harus senantiasa dilindungi. 
Dari uraian tersebut diatas, perlu diingat bahwa yang digambarkan adalah pesantren yang masih dalam bentuknya yang murni, atau dalam studi kepesantrenan disebut dengan istilah pesantren tradisional, sehingga kalau kita menengok perkembangan pesantren saat sekarang tentunya akan dapat kita lihat usaha-usaha untuk mendorong terjadinya perubahan pada unsurunsur pesantren,disesuaikan dengan dinamika dan kemajuan zaman.

\section{KESIMPULAN}

Model pendidikan Islam di pesantren yaitu sebuah model yang memuat proses yang dilakukan untuk menciptakan manusia-manusia yang seutuhnya; beriman dan bertaqwa kepada Tuhan serta mampu mewujudkan eksistensinya sebagai khalifah Allah dimuka bumi, yang berdasarkan kepada ajaran Alqur'an dan Sunnah.

Pondok Pesantren adalah lembaga pendidikan yang berorientasi pada pendidikan agama. Yang mencetak agamanya untuk menjadi ahli agama guana bermanfaat bagi masyarakat. Pondok Pesantren adalah lembaga pendidikan agama yang di dalamnya banyak berbagai unsur pendukungnya, yaitu: kyai, santri, kitab kuning, masjid dan pondok itu sendiri. Seiring perkembangan, pondok pesantren memperbaiki diri untuk meningkatkan kualitasnya.

Model Pendidikan di dalam AlQur'an diistilahkan dengan ta'dib, yang berasal dari kata kerja "addaba". Kata alta'dib diartikan kepada proses mendidik yang lebih tertuju pada pembinaan dan penyempurnaan akhlak atau budi pekerti peserta didik. Kata ta'dib tidak dijumpai langsung dalam al- 
Syaiful Anam : Pendidikan Pesantren Sebagai Model Yang Ideal Dalam Pendidikan Islam

Qur'an, tetapi pada tingkat operasional, pendidikan dapat dilihat pada praktek yang dilakukan oleh Rasulullah. Rasul sebagai pendidik agung dalam pandangan pendidikan Islam, sejalan dengan tujuan Allah mengutus beliau kepada manusia yaitu untuk menyempurnakan akhlak 
Syaiful Anam : Pendidikan Pesantren Sebagai Model Yang Ideal Dalam Pendidikan Islam

\section{DAFTAR PUSTAKA}

Abud, Abd al- Ghani ', Dirasat Muqaranat li Tarikh al - Tarbiyah, Kairo : Dar al- Fikr al-Arabi, 1987.

Al- attas, syed Muhammad Naquib, The concept of education in Islam : A framework for an Islamic philosophy of education. Kuala lumpur : International Institute of Islamic Thought and civilization(Istac), 1980.

Ali, Muhamad Daud. dan Hj. Habiba Daud S.H. Lembaga-lembaga Islam di Indonesia. Jakarta : PT Raja Grafindo Persada, 1995.

Anshari, Endang Saifuddin. Pokok-pokok Pikiran tentang Islam. Jakarta : Usaha Interprise, 1976.

Arif, Armai, M. A. Pengantar Ilmu dan Metodologi Pendidikan Islam. Jakarta : Ciputat Press, 2002.

Arifin, H.M. Ilmu Pendidikan Islam. Jakarta: Bumi Aksara,1991.

Azra, Azyumardi. Esei-esei intelektual Muslim dan Pendidikan Islam. Jakarta: logos wacana ilmu, 1998.

Dewan Redaksi, Ensiklopedia Islam. Jakarta: Ichtiar baru Van Hove, 1993.

Imam Bawani, Tradisionalisme dalam Pendidikan Islam. Surabaya: Al-Ikhlas, 1993.

KBBI. Kamus Besar Bahasa Indonesia, (KBBI). [online] available at : [diakses 28 Februari 2019].

Lubis, Saiful Akhyar. Konseling Islami Kyai dan Pesantren. Yogyakarta, eLSAQ Press, 2007

Munawwir, Ahmad Warson. Kamus al-Munawwir. Surabaya: Pustaka Progresif, 1997.

Natsir, Mohammad. Capita Selekta, jilid I \& II. Jakarta: Bulan Bintang, 1973.

Nizar, Samsul, Pengantar Dasar-Dasar Pemikiran Pendidikan Islam. Jakarta: Gaya Media Pratama, 2001. 
Syaiful Anam : Pendidikan Pesantren Sebagai Model Yang Ideal Dalam Pendidikan Islam

Tafsir, Ahmad. Filsafat Pendidikan Islami. Bandung: Remaja Rosdakarya 2006.

Takdir, Muhammadi. Revitalisasi Pendidikan Berbasis Moral. Yogyakarta: Ar-Ruzz Media, 2012.

Umar, Bukhari. Imu pendidikan Islam. Jakarta: Amzah, 2012.

Undang-Undang Nomor 20 Tahun 2003, Tentang Sistem Pendidikan Nasional. Jakarta: Depdiknas, 2003.

Usa, Muslih (ed), Pendidikan Islam di Indonesi: Antara Cita dan Fakta. Yogyakarta: Tiara Wacana Yogya, 1991.

Wahid, Abdurrahman. Menggerakkan Tradisi Esai-esai Pesantren. Yogyakarta: Lkis,2001 